\title{
Extreme snow metamorphism in the Allan Hills, Antarctica, as an analogue for glacial conditions with implications for stable isotope composition
}

\author{
Ruzica DADIC, ${ }^{1}$ Martin SCHNEEBELI, ${ }^{2}$ Nancy A.N. BERTLER, ${ }^{1,3}$ \\ Margit SCHWIKOWSKI, ${ }^{4}$ Margret MATZL ${ }^{2}$ \\ ${ }^{1}$ Antarctic Research Centre, Victoria University of Wellington, Wellington, New Zealand \\ ${ }^{2}$ WSL Institute for Snow and Avalanche Research SLF, Davos Dorf, Switzerland \\ ${ }^{3}$ Institute of Geological and Nuclear Sciences Ltd, Lower Hutt, New Zealand \\ ${ }^{4}$ Paul Scherrer Institut, Villigen PSI, Switzerland \\ Correspondence: Ruzica Dadic <ruzica.dadic@vuw.ac.nz>
}

\begin{abstract}
Understanding physical processes in near-zero accumulation areas can help us to better understand polar ice-core records, particularly during periods when accumulation rates were lower than today. We report measurements from a $5 \mathrm{~m}$ firn core from the Allan Hills, Antarctica, which include physical properties using computer tomography, stable isotope ratios $\delta \mathrm{D}$ and $\delta^{18} \mathrm{O}$, and ${ }^{210} \mathrm{~Pb}$ activity. The core shows a highly metamorphosed firn with homogeneous and stable structure, but with discrete layers near the surface. The observed firn structure is caused by a combination of unique depositional and post-depositional processes. The irregular $\delta \mathrm{D}$ and $\delta^{18} \mathrm{O}$ signal does not follow the stratigraphic sequence and implies post-depositional modification caused by microscopic pressure gradients in the firn that can result from either forced ventilation over rough surfaces in the presence of wind or alternating temperature-gradients between the firn and the atmosphere. Our results also indicate impact snow deposition under high winds and with a high initial density and air exchange between the atmosphere and the snowpack. ${ }^{210} \mathrm{~Pb}$ activity below $0.3 \mathrm{~m}$ falls below the detection limit, implying that most of the core is more than $\mathbf{1 0 0}$ years old. We conclude that the Allan Hills record provides a unique opportunity to investigate important processes that would have affected ice-core records from glacial periods.
\end{abstract}

KEYWORDS: atmosphere/ice/ocean interactions, polar firn, recrystallization, snow metamorphosis, snow/ice surface processes

\section{INTRODUCTION}

Deep Antarctic ice cores have revolutionized our understanding of climate conditions and drivers for the past eight glacial cycles (Jouzel and others, 2007a). However, dating of ice cores depends on the determination of gas-ice age differences and the interpretation of temperature changes from isotopes, which are sensitive to net snow accumulation changes, bubble close-off differences and firn-column properties, all of which change significantly between glacial and interglacial time periods (Masson-Delmotte and others, 2006; Parrenin and others, 2013).

Snow metamorphism is a primary driver of the transition from snow to ice and can be accompanied by altered isotopic compositions and chemical species concentration. Highly metamorphosed snow results in major structural changes, and is poorly understood but has been identified in few places in Antarctica. Albert and others (2004) and Courville and others (2007) described the physical properties of highly metamorphosed snow in the megadunes of East Antarctica, but properties of snow and firn patches within blue-ice fields, such as the Allan Hills, have not been discussed so far.

Low-accumulation regions can experience significant vapour-pressure gradient driven metamorphism, caused by either wind-driven ventilation or long-term alternating temperature-gradients (Pinzer and Schneebeli, 2009). Forced ventilation can also cause vapour exchange between the snow and the atmosphere (Moser and Stichler, 1974; Sommerfeld and others, 1987; Colbeck, 1989; Town and others, 2008; Steen-Larsen and others, 2014) and further affect the snow structure and isotopic composition. In addition to the large amount of metamorphism that affects the snow post-depositionally, the snow in the Allan Hills is unique because it is deposited under strong winds and therefore with a high initial density, resulting in a highdensity snowpack.

Stable isotope composition of precipitation is closely linked to local air temperature (Dansgaard, 1964), and changes in $\delta \mathrm{D}$ and $\delta^{18} \mathrm{O}$ can be interpreted as local temperature variations, changes in moisture-source region, the seasonality of the snowfall, changes in sea-surface temperature, atmospheric circulation, cloud temperature and the height of the inversion layer in the interior of the ice sheets (Cuffey and others, 1995; Kavanaugh and Cuffey, 2003) or post-depositional modifications. Numerous studies discuss the relationship between regional temperature and isotope concentrations in ice cores to obtain past temperature reconstructions (e.g. Dansgaard, 1964; Lorius and Merlivat, 1977; Dahe and others, 1994; Cuffey and others, 1995; Steig and others, 1998; EPICA Community Members, 2004; Masson-Delmotte and others, 2008). In general, the $\delta^{18} \mathrm{O}$ and $\delta \mathrm{D}$ ratio is less negative with increasing accumulation rate and increasing temperature (Dansgaard, 1964), if post-depositional processes are neglected. Post-depositional 
changes, however, can significantly alter the isotopic signal and further complicate the interpretation of ice-core records (Moser and Stichler, 1974; Sommerfeld and others, 1987, 1991; Friedman and others, 1991; Cunningham and Waddington, 1993; Waddington and others, 1996; McConnell and others, 1998; Stichler and others, 2001; Albert and others, 2004; Neumann and Waddington, 2004; Town and others, 2008; Ekaykin and others, 2009; Sokratov and Golubev, 2009; Steen-Larsen and others, 2014). Isotopic ratios can be altered by diffusion processes (through kinetic fractionation) and by phase changes (through equilibrium fractionation) in the snowpack (McConnell and others, 1998; Jouzel and others, 2007b). First, the amplitude of the isotopic signal in snow, and the seasonal signal in particular, is smoothed with time through molecular diffusion processes, which can homogenize the isotopic record over small timeand length-scale without alteration of the mean isotope content (Langway, 1967; Whillians and Grootes, 1985; Cuffey and Steig, 1998; Johnsen and others, 2000). Johnsen and others (2000) identified diffusion lengths for Greenland to be 7-10 cm, which would only affect the seasonal signal. For lower accumulation rates, however, the diffusion length of $10 \mathrm{~cm}$ can influence decades of accumulation and possibly diminish not only the seasonal but also a longerlasting climatic signal. Second, the isotopic signal in snow can be altered due to water-vapour exchange between the atmosphere and the near-surface snowpack. Numerous, mostly theoretical, studies have addressed the equilibrium fractionation and the resulting relationship between the sign or magnitude of ice sublimation or deposition and trends in isotopic changes in surface snow (Epstein and others, 1965; Jouzel and others, 1997; Ekaykin and others, 2002; Waddington and others, 2002; Neumann, 2003; Neumann and Waddington, 2004; Town and others, 2008). There has been a general consensus that when water vapour condenses, the heavy isotopologues become enriched in the liquid-solid phase, while the vapour becomes depleted in the heavy isotopologues. Steen-Larsen and others (2014), however, have been unable to identify any systematic relationship between the sign or magnitude of sublimation or deposition and trends in isotopic changes in measurements of surface snow and conclude that post-depositional changes are caused by changes in the near-surface atmospheric water-vapour isotopic composition, which is driven by 'synoptic variations and changes in air mass trajectories', large-scale winds and moisture advection. The uptake of the atmospheric water vapour is further controlled by continuous recrystallization in the snow (Pinzer and others, 2012; SteenLarsen and others, 2014) and replacement of the pore-space water vapour in snow with atmospheric water vapour. The continuous recrystallization and large mass turnover, as observed by Pinzer and others (2012) and modelled by Steen-Larsen and others (2014), leads to a rapid imprint of changes in near-surface water-vapour isotopic composition in surface snow (Steen-Larsen and others, 2014).

The deuterium excess $d\left(d=\delta \mathrm{D}-8 \times \delta^{18} \mathrm{O}\right.$; Dansgaard, 1964 ) is often interpreted as an indicator of the temperature and relative humidity at the moisture source (e.g. Dansgaard, 1964; Merlivat and Jouzel, 1979; Delmotte and others, 2000) and reflects the 'kinetic fractionation occurring during non-equilibrium fractionation processes such as evaporation above the ocean' (Vimeux and others, 2001), sublimation at very low temperatures or condensation (Cappa and others, 2003), including the recrystallization in the snowpack (Steen-Larsen and others, 2014). The kinetic effect is a function of the relative humidity of air and depends on the size and the geometry of crystals (Luz and others, 2009). It becomes stronger with decreasing temperature and increasing wind speed, conditions generally occurring during cold periods or in dry and windy areas such as the Allan Hills. Kinetic fractionation is associated with water-vapour diffusion, owing to different diffusivities for the isotopically different water molecules in air and resulting in stronger fractionation between hydrogen $\left({ }^{1} \mathrm{H}\right)$ and deuterium $\left({ }^{2} \mathrm{H}\right)$ than between ${ }^{16} \mathrm{O}$ and ${ }^{18} \mathrm{O}$ because of smaller relative mass differences of the oxygen isotopes (Merlivat, 1978; Cappa and others, 2003; Luz and others, 2009). Negative $d$ values are therefore uncommon but have been reported from coastal locations and the Dry Valleys in Antarctica (Masson-Delmotte and others, 2008; Bertler and others, 2011). Negative $d$ values occur in particular when air masses with enriched isotope values are precipitated at extremely low temperatures (Kavanaugh and Cuffey, 2003) and can also be associated with exceptionally long and continuous post-depositional evaporation/sublimation processes, such as may occur in the Allan Hills. Bertler and others (2011) found a sharp transition from positive to negative average $d$ values in the Dry Valleys at the onset of the Little Ice Age (LIA), around AD 1400, which responded to lower temperatures and reduced relative humidity, perhaps resulting from a larger, more active Ross Sea polynya due to stronger katabatic winds during this period. MassonDelmotte and others (2008) found that all sites with negative $d$ are below $2400 \mathrm{~m}$ a.s.l. and thus might be caused by wind ablation effects, which reduce accumulation and therefore increase the residence time of snow crystals in the surface zone characterised by strong temperature gradients'. The strong temperature gradients and forced ventilation induce pressure gradients and moisture movement within the snowpack as well as water-vapour exchange between the firn and the atmosphere, leading to isotopic fractionation in the firn.

The water-vapour movement can be intensified by pressure differences caused by wind-driven ventilation in the near-surface (Waddington and others, 1996; Albert, 2002; Neumann, 2003; Town and others, 2008) and by macroscopic temperature gradients. Post-depositional isotopic modifications in the snowpack and snow metamorphism are dependent on the duration of snow exposure to the atmosphere (Moser and Stichler, 1974), which, for lowaccumulation areas such as the Allan Hills, can be hundreds of years. The duration and depth of the isotopic modifications in the snowpack also depend, to a lesser degree, on recrystallization activity due to snow compaction (likely to be low in the Allan Hills) and molecular diffusion of water vapour (Johnsen and others, 2000). Both of these processes can continue for hundreds of years and affect the entire firn column (Whillians and Grootes, 1985; Johnsen and others, 2000).

The aim of this paper is to improve our understanding of the physical properties and isotopic composition of firn in low-accumulation regions. We analyse a $5 \mathrm{~m}$ firn core collected next to a blue-ice field in the Allan Hills, Antarctica. First, we discuss physical properties; in particular density, specific surface area (SSA) and average thickness of the ice structure and pore space as determined by microcomputed tomography (micro-CT). To date, there are no existing SSA measurements for snow from very low- 
accumulation regions. Second, we investigate the stable isotope ratios, $\delta^{18} \mathrm{O}$ and $\delta \mathrm{D}$, as well as deuterium excess, $d$ $\left(d=\delta \mathrm{D}-8 \times \delta^{18} \mathrm{O}\right.$; Dansgaard, 1964). Third, we discuss the ${ }^{210} \mathrm{~Pb}$ activity in order to estimate the age of the firn.

Our hypothesis is that the unique snow structure and the stable isotope composition in the Allan Hills snow is caused by: (1) microscopic pressure gradients in the firn that are the result of either forced ventilation over rough surfaces in the presence of wind or alternating seasonal temperaturegradients that this snow has been exposed to, because of low accumulation rates that cause the snow to stay near the surface for a long time; (2) high-impact wind-driven snow deposition, which results in a high initial density; and (3) increased vapour transport due to forced wind ventilation and air exchange between the atmosphere and the snowpack, which is active during the long residence time of snow near the surface. Furthermore, we estimate that the measured firn core is older than any snow previously encountered at the given depth ( $~ 660$ years at $5 \mathrm{~m}$ depth, and maybe older) and is a possible analogue for cold and windy glacial conditions, with accumulation lower than that of today.

\section{METHODS}

Antarctic blue-ice areas occupy about $1 \%$ of the Antarctic ice-sheet surface. They are usually located near rock outcrops and are characterized by high winds and net ablation (Bintanja, 1999). Blue-ice areas have been studied because of their importance in the search for meteorites (Whillans and Cassidy, 1983; Cassidy and others, 1992; Harvey and others, 1998), for their peculiar meteorological conditions and negative surface mass balance (Bintanja and van den Broeke, 1995; Bintanja, 1999; Bintanja and Reijmer, 2001), because of their potential for palaeoclimate reconstructions using ice cores (Spaulding and others, 2012, 2013) and as an analogue for Snowball Earth scenarios because of their unique ice surface (Dadic and others, 2013).

Here we report on a $5 \mathrm{~m}$ firn core collected from a snowpatch within a blue-ice field in the Allan Hills $\left(-76.67^{\circ}\right.$, 159.23 ; Fig. 1) in January 2011. The location of the core was the Allan Hills Main Ice Field, which is dominated by sublimating blue ice. Local topographical depressions facilitate the formation of small accumulating snowpatches within the ice field. The low ice velocities $\left(\sim 0.16 \mathrm{~m} \mathrm{a}^{-1}\right.$ for the closest measured point on blue ice, P10, in Spaulding and others (2012)) cause that accumulated snow to be preserved in these topographic depressions for many hundreds of years, before it reaches sublimating areas.

The core was transported from the field camp (stored in a snowdrift at temperatures of $-20^{\circ} \mathrm{C}$ to $-30^{\circ} \mathrm{C}$ ) to McMurdo station's Crary Laboratory (at $-30^{\circ} \mathrm{C}$ ) in plastic ice-core sleeves, was cut at McMurdo station into $\sim 30 \mathrm{~cm}$ pieces and was shipped (at $-60^{\circ} \mathrm{C}$ during transport) to the WSL Snow and Avalanche Institute (SLF) in Davos, Switzerland, where it was stored at $-25^{\circ} \mathrm{C}$ before cutting for the different analyses. We assume that no significant structural changes have taken place in the firn during storage. Core analyses include physical properties, stable water isotope ratios and ${ }^{210} \mathrm{~Pb}$ activity.

\section{Physical properties using micro-CT}

We have micro-CT scans from eight firn samples in the depth range 61-469 cm (evaluated in March 2012). We

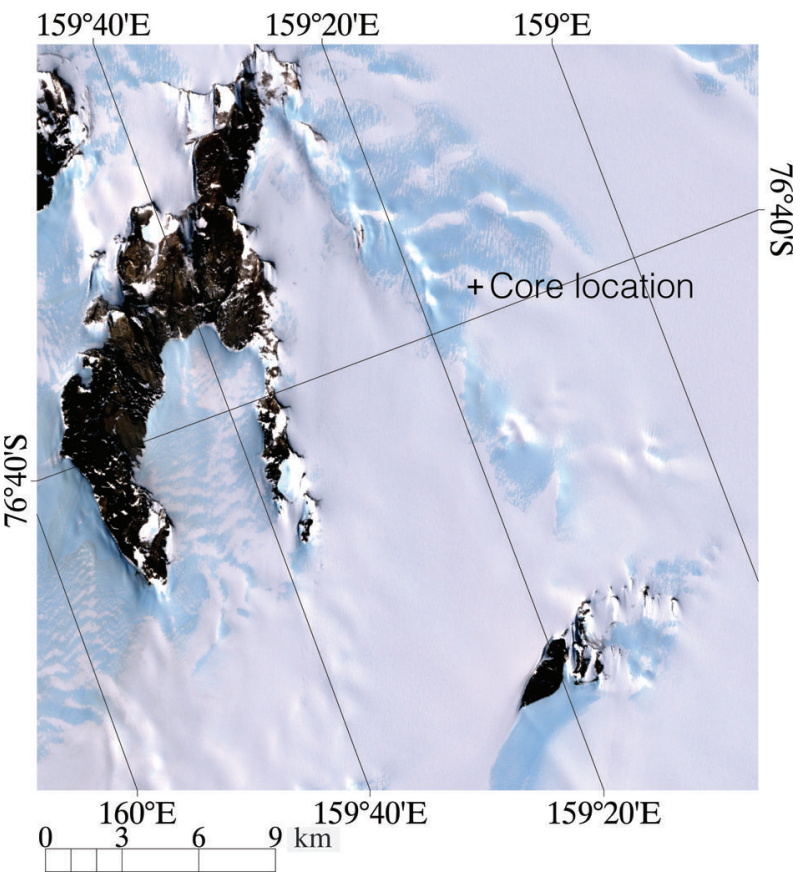

Fig. 1. Allan Hills, Antarctica, from Landsat Mosaic of Antarctica (Bindschadler and others, 2008) with location of the firn core.

used the same instruments and procedures as described by Dadic and others (2013) to image and measure the microstructural properties of the snow and firn samples. As well as the eight samples below $61 \mathrm{~cm}$, we have additional scans from three cast samples in the depth range $0-36 \mathrm{~cm}$ (evaluated in August-October 2011, every 1 vertical mm). The cast samples were collected from a shallow snow pit, $\sim 50 \mathrm{~m}$ from the location of the $5 \mathrm{~m}$ core. The samples were cast with diethyl phtalate (Heggli and others, 2009), preserving the snow structures during transport and storage.

Firn samples for the micro-CT were first cored to a diameter of $36 \mathrm{~mm}$ using a plug cutter. Imaging was performed using a micro-CT 40 (Scanco Medical) computer tomograph. The field of view was $37 \mathrm{~mm}$, effective voxel size $36 \mu \mathrm{m}$, peak X-ray energy $55 \mathrm{kV}$, intensity $145 \mathrm{~A}$ and shutter time $400 \mathrm{~ms}$. The 16-bit greyscale images were then filtered using a $3 \times 3 \times 3$ Gaussian filter with a standard deviation of 1.5 voxels and segmented (Dadic and others, 2013). The segmentation threshold for distinguishing between air and firn was 120 and was selected because it was in the middle of the trough between the peaks of air and ice in the histogram. The relatively low resolution in this study ( $36 \mu \mathrm{m}$, as opposed to the usual $18 \mu \mathrm{m}$ resolution used in recent studies) can decrease the SSA by up to $20 \%$ and the pore-and-ice structure thickness by up to $17 \%$ (Schneebeli and Sokratov, 2004). Since all our samples were measured using the same resolution and we are discussing relative differences with depth, the resolution effect is insignificant. The pore-and-ice structure thickness was determined by evaluating the micro-CT images with the algorithm used by Hildebrand and Rüegsegger (1997). If the pore-and-ice structures were perfect isolated spheres, each modelled sphere would represent exactly one bubble/ice sphere. Because the pore-and-ice structures in our samples were not spheres, the size rather represents the average curvature of partial spheres. This technique is like virtual sieving; it gives the size distribution as if we had sieved the pore space or ice structures. 


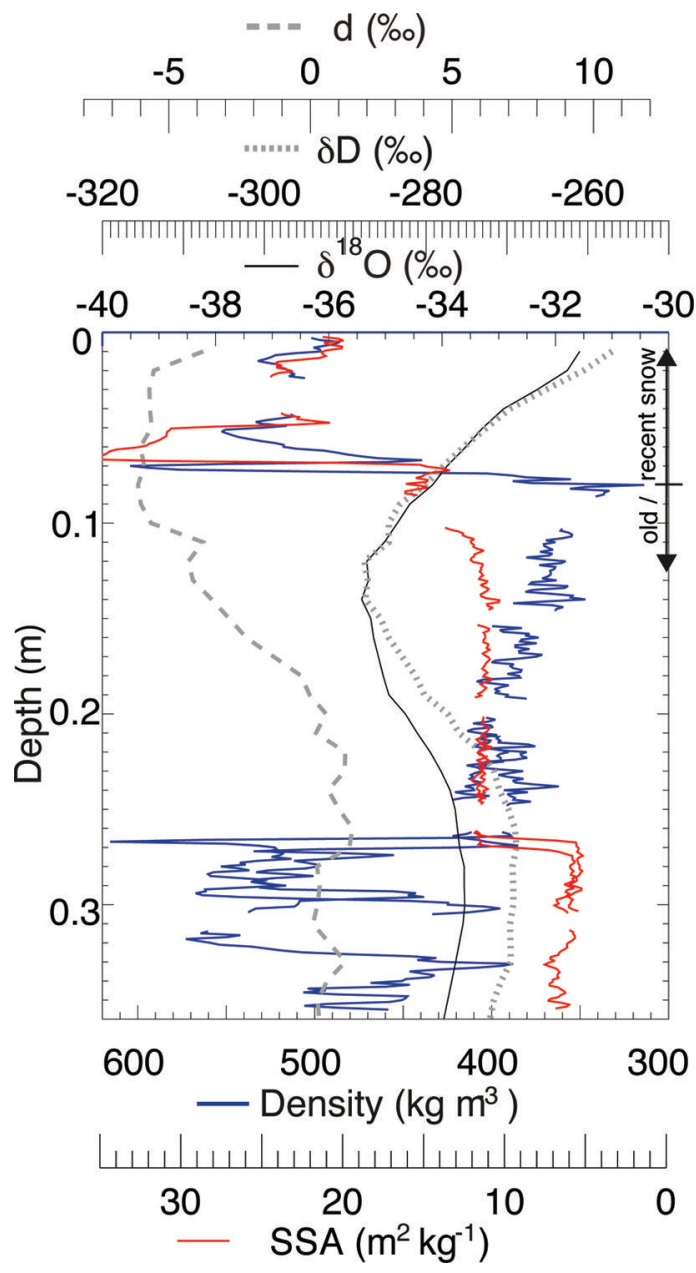

Fig. 2. Near-surface density and SSA (measured by micro-CT), $\delta^{18} \mathrm{O}, \delta \mathrm{D}$ and deuterium excess $d$. Note that the density and SSA scales are reversed.

\section{${ }^{210} \mathrm{~Pb}$ activity}

${ }^{210} \mathrm{~Pb}$ is a naturally occurring radioactive isotope with a halflife of 22.3 years that is produced in the ${ }^{238} \mathrm{U}$ decay chain via the intermediate isotope ${ }^{222} \mathrm{Rn} .{ }^{222} \mathrm{Rn}$ has a half-life of 3.8 days and, because it is a gas, emanates constantly from the Earth's crust into the atmosphere. In the atmosphere it decays over several intermediate isotopes to ${ }^{210} \mathrm{~Pb}$, which attaches to aerosols and settles onto snow surfaces by dry or wet deposition within a few days to weeks. Owing to radioactive decay, the activity of ${ }^{210} \mathrm{~Pb}$ in firn decreases with depth and can therefore be used for dating. The period accessible for dating depends mainly on the half-life and was found to be on a century timescale (Gäggeler and others, 1983). This is the case for (1) constant accumulation of ${ }^{210} \mathrm{~Pb}$ in the snow and (2) if no relocation of the initial ${ }^{210} \mathrm{~Pb}$ occurred (Gäggeler and others, 1983).

The activity of ${ }^{210} \mathrm{~Pb}$ was measured at the Laboratory of Radiochemistry and Environmental Chemistry, Paul Scherrer Institut, indirectly from the activity of its granddaughter nuclide ${ }^{210}$ Po electrolytically deposited on Ag plates. The ${ }^{210} \mathrm{Po}$ activity was determined by measuring its alpha decay at an energy of $5.3 \mathrm{MeV}$ using an $\alpha$-spectrometer (Enertec Schlumberger 7164) with Polar Ice Prediction System (PIPS) detectors. Overall, 17 samples were prepared in May 2011 and measured in August 2011. The ${ }^{210} \mathrm{~Pb}$ activity in the $5 \mathrm{~m}$ core was measured with a resolution of $\sim 20-40 \mathrm{~cm}$ (which was determined by the amount of snow necessary for the analysis).

\section{Stable isotopes $\delta^{18} \mathrm{O}$ and $\delta \mathrm{D}$}

We measured the stable isotope composition of the $5 \mathrm{~m}$ snow core with a $1 \mathrm{~cm}$ resolution for the top $50 \mathrm{~cm}$ (cut in April 2011, measured in May 2011), and approximately $5 \mathrm{~cm}$ resolution for the rest of the core (cut in May 2011, measured in August 2011). The samples were cut in the cold laboratory at the SLF, filled into vials while still frozen, and then shipped in liquid form to the Stable Isotope Laboratory at GNS Science, Wellington, New Zealand, where they were processed.

Stable isotopic ratios $\left(\delta^{18} \mathrm{O}\right.$ and $\left.\delta \mathrm{D}\right)$ of the samples were measured with a GVI IsoPrime mass spectrometer. The analytical precision for the instrument is $\pm 0.1 \%$ o for $\delta^{18} \mathrm{O}$, $\pm 1.0 \%$ o for $\delta \mathrm{D}$, resulting in an uncertainty of $\pm 1.3 \%$ on the second-order parameter, deuterium excess $d$.

\section{RESULTS}

\section{Physical properties in the top $5 \mathrm{~m}$ of a snowpatch with very low accumulation}

The density in the top $36 \mathrm{~cm}$ ranges from 313 to $615 \mathrm{~kg} \mathrm{~m}^{-3}$ (Fig. 2). The density profile shows high-density snow $\left(>500 \mathrm{~kg} \mathrm{~m}^{-3}\right)$ in the top $8 \mathrm{~cm}$, overlying a layer of lowerdensity snow (350-400 $\mathrm{kg} \mathrm{m}^{-3}$ ) down to around $26 \mathrm{~cm}$. Below $26 \mathrm{~cm}$, snow density is high again (400-600 $\mathrm{kg} \mathrm{m}^{-3}$ ). The density of the eight firn samples between 61 and $469 \mathrm{~cm}$ remains high, ranging from 515 to $614 \mathrm{~kg} \mathrm{~m}^{-1}$ (Fig. 3a). The density is lowest in the top $1 \mathrm{~m}$, and there is no clear trend below $1 \mathrm{~m}$. The SSA is as high as $35.0 \mathrm{~m}^{2} \mathrm{~kg}^{-1}$ in the top $8 \mathrm{~cm}$ and rapidly decreases to $\sim 10 \mathrm{~m}^{2} \mathrm{~kg}^{-1}$ at $8 \mathrm{~cm}$ and to $\sim 5-6 \mathrm{~m}^{2} \mathrm{~kg}^{-1}$ at $26 \mathrm{~cm}$ (Fig. 2). Below $61 \mathrm{~cm}$, the specific surface area (SSA) ranges between 1.8 and $4.6 \mathrm{~m}^{2} \mathrm{~kg}^{-1}$, exponentially decreasing with depth (Fig. 3a). The change in SSA with depth (Fig. 3a, dashed line) is $\sim-2.3 \mathrm{~m}^{2} \mathrm{~kg}^{-1} \mathrm{~m}^{-1}$ at the surface and decreases to $\sim-0.1 \mathrm{~m}^{2} \mathrm{~kg}^{-1} \mathrm{~m}^{-1}$ at $5 \mathrm{~m}$ depth. Both the density and the SSA in the top $36 \mathrm{~cm}$ show discrete layers. Because of the lower vertical resolution below $61 \mathrm{~cm}$, we cannot determine whether the layering is persistent with depth. However, we did not find distinctive layers when we visually inspected the core.

The ice structures throughout the measured firn column below $60 \mathrm{~cm}$ are rounded and, apart from the pore thickness and ice-structure thickness increase with depth (Fig. 3b), show little change in geometry (Fig. 4). Both ice-structure and pore-space thickness increase almost linearly with depth (Fig. 3b), with ice-structure thickness increasing at a rate $\left(0.258 \mathrm{~mm} \mathrm{~m}^{-1}\right)$ twice that of pore-structure thickness $\left(0.126 \mathrm{~mm} \mathrm{~m}^{-1}\right)$. The core shows a gradual change in all measured physical parameters (SSA, average ice/pore thickness) except density (Fig. 3). SSA and ice-structure thickness are inversely proportional.

\section{Snow-age estimates using ${ }^{210} \mathbf{P b}$ activity}

Except for the top $0.3 \mathrm{~m}$ which shows a ${ }^{210} \mathrm{~Pb}$ activity of $16 \mathrm{mBq} \mathrm{kg}^{-1}$, no activity above the blank value $(1.13 \pm$ $0.33 \mathrm{mBq} \mathrm{kg}^{-1}$ ) was detected in the remainder of the core (Fig. 5). Assuming a constant flux of ${ }^{210} \mathrm{~Pb}$ from the atmosphere to the snow, the ${ }^{210} \mathrm{~Pb}$ can be used to provide age information and the corresponding accumulation rates. 


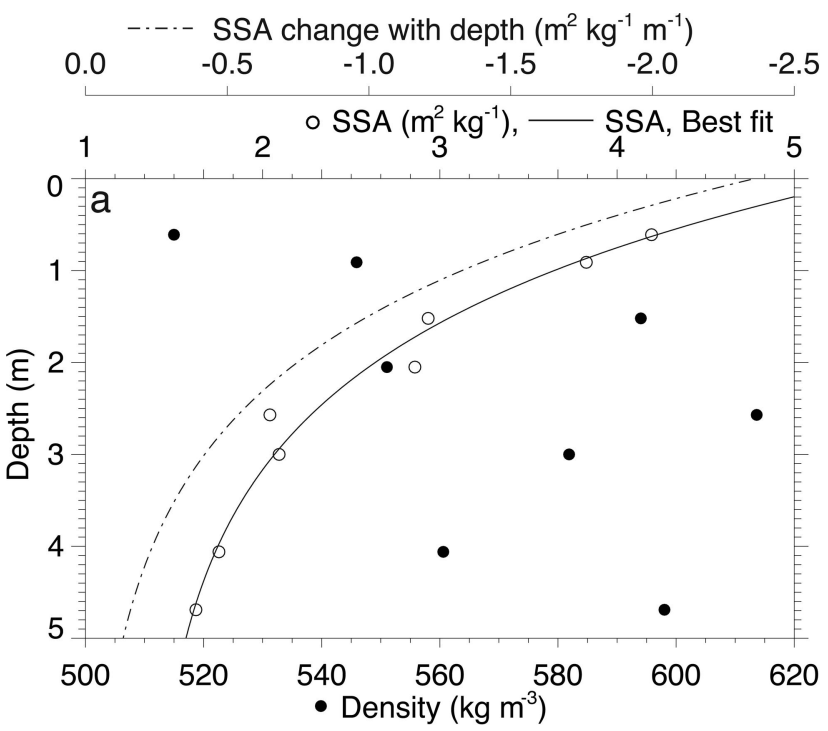
$\begin{aligned} & \text { Best fit: } \text { Pore structure }=0.504+0.126 \times \operatorname{depth}(\mathrm{m}) \\ & \text { Ice structure }=0.415+\mathbf{0 . 2 5 8} \times \operatorname{depth}(\mathrm{m})\end{aligned}$

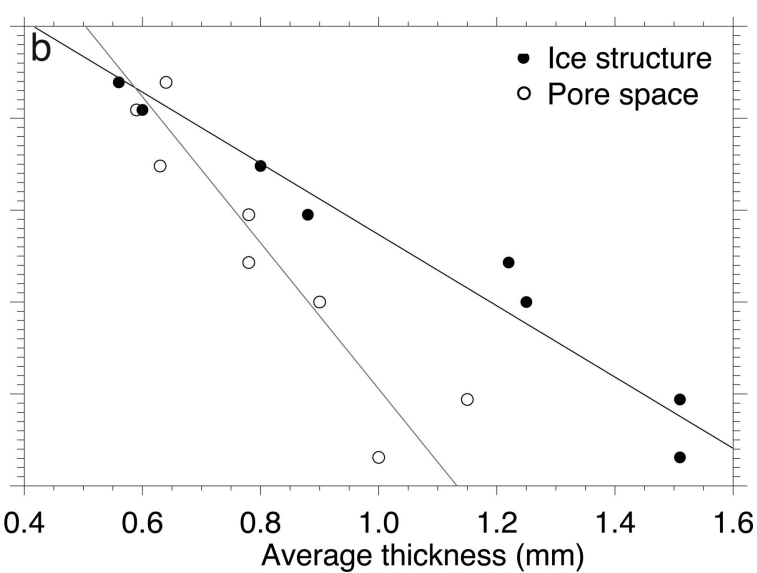

Fig. 3. (a) Density vs depth (dots) and SSA vs depth (cycles). Black line is the best fit to SSA data $\left(\mathrm{SSA}=4.1+5.23^{-0.0035 * \text { depth }}+1.34\right.$ ); dashed line is slope of the best fit and shows the change of SSA with depth. (b) Average ice-structure thickness vs depth (dots) and average pore space thickness (circles) vs depth. Solid lines are best fit to data, with slope of the best fit being the change in thickness with depth. See Methods for detailed explanation of ice structure and pore space thickness.

${ }^{210} \mathrm{~Pb}$ has previously been used in snow to reveal the fluctuation of the temporal variability of snow accumulation (Crozaz and others, 1964; Suzuki and others, 2004). Since ${ }^{210} \mathrm{~Pb}$ has a half-life of 22.3 years, it can be used to date snow layers from approximately the last century. Owing to the short half-life, we expect no ${ }^{210} \mathrm{~Pb}$ activity in firn older than 100 years.

Surface activity of ${ }^{210} \mathrm{~Pb}$ at the closest site with data is 20 $25 \mathrm{mBq} \mathrm{kg}^{-1}$ at Taylor Dome (Morse and others, 1999), but is closer to $30 \mathrm{mBq} \mathrm{kg}^{-1}$ if other data ( $\beta$ activity) at that site are taken into account. About $30 \mathrm{mBq} \mathrm{kg}^{-1}$ is also the activity that was measured at the South Pole Station (Crozaz and others, 1964; Sanak and Lambert, 1977). The top layer $(0.3 \mathrm{~m})$ has an activity of $16 \mathrm{mBq} \mathrm{kg}^{-1}$. Because we cannot distinguish if this activity is representative of the entire $0.3 \mathrm{~m}$, or if there is a high-activity surface sublayer, we will treat the data as representative for the $0.3 \mathrm{~m}$ layer in the following discussion. Equation 1 from Crozaz and others (1964) assumes that the initial ${ }^{210} \mathrm{~Pb}$ concentration in the precipitation at a given place remains constant, and remains valid even in case of variable accumulation rates

$$
A_{h}=A_{0} \mathrm{e}^{-\lambda t},
$$

where $A_{h}$ is the measured ${ }^{210} \mathrm{~Pb}$ activity at depth $h, A_{0}$ the ${ }^{210} \mathrm{~Pb}$ activity at the surface, $\lambda$ the radioactive decay constant for ${ }^{210} \mathrm{~Pb}\left(0.032 \pm 0.001 \mathrm{a}^{-1}\right)$ and $t$ time (years). For the measured activity of $16 \mathrm{mBq} \mathrm{kg}^{-1}$ in the top $0.3 \mathrm{~m}$, Eqn (1) results in an age of $\sim 20$ years, assuming $A_{0}$ of $30 \mathrm{mBq} \mathrm{kg}^{-1}$.

We assumed that the measured activity is representative for the middle of that $0.3 \mathrm{~m}$ layer, because the ice mass needed to measure ${ }^{210} \mathrm{~Pb}$ did not allow a higher vertical resolution. We estimate an accumulation rate of $0.0075 \mathrm{~m} \mathrm{a}^{-1}(0.15 \mathrm{~m}$ per 20 years). If we further assume $0.0075 \mathrm{ma}^{-1}$ to be a constant accumulation rate for the remainder of the core, the age estimate for the negative peak in $\delta \mathrm{D} / \delta^{18} \mathrm{O}$ at $2.5 \mathrm{~m}$ is $\sim 330$ years and the bottom of the core is $\sim 660$ years (AD 1350). The negative peak period between 200 and $300 \mathrm{~cm}$ would have an age of $\sim 260$ 400 years (AD 1610-1750). The positive peak in $d$ from 50 to $100 \mathrm{~cm}$ would be $\sim 70-130$ years ago (AD 1880-1940).
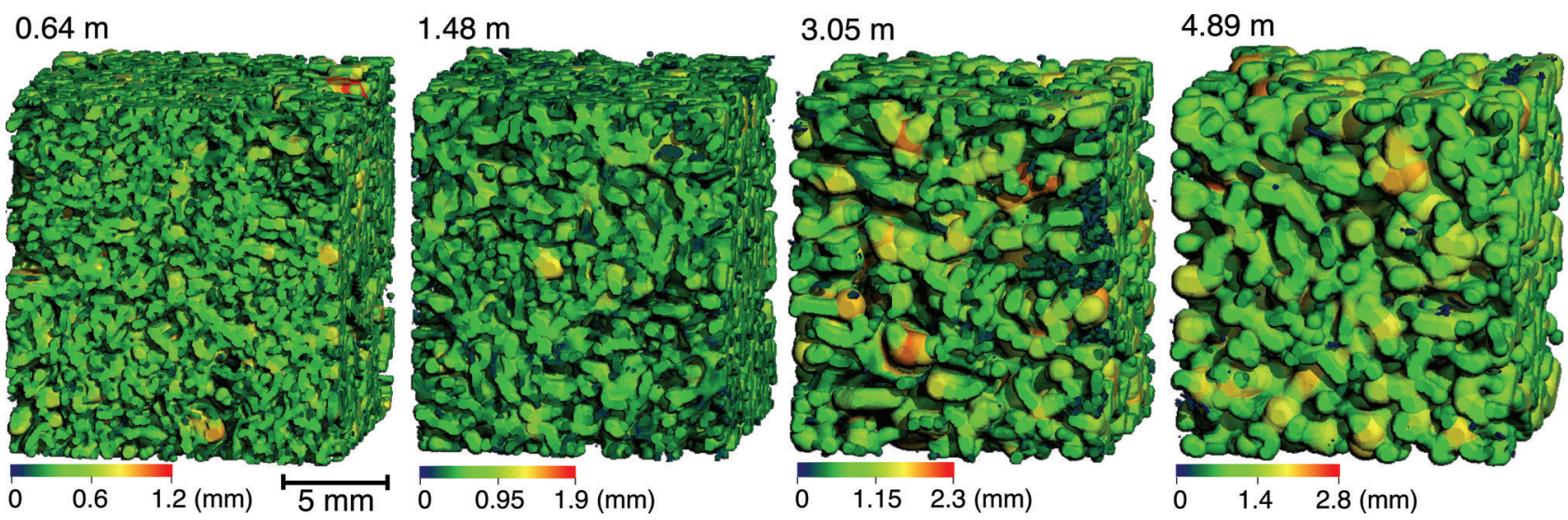

Fig. 4. Micro-CT models of sampled snow in the Allan Hills. The coloured regions are ice structures; air is blank. Colours indicate icestructure thickness and are scaled for each image individually. 


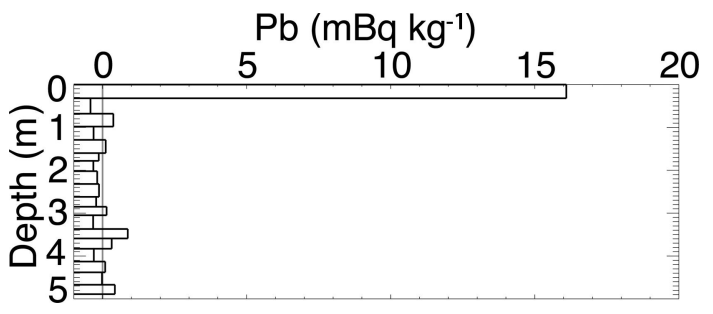

Fig. 5. ${ }^{210} \mathrm{~Pb}$ activity with depth. Values below $30 \mathrm{~cm}$ are within the uncertainty of the measurement and can be assumed to be blanks.

Assuming an ice velocity of $0.16 \mathrm{ma}^{-1}$ (closest measured velocity (P10) in Spaulding and others (2012), the bottom of the core was $160 \mathrm{~m}$ upstream 1000 years ago, and was well within the topographic depression and accumulation area in which it is located today.

\section{$\delta^{18} \mathrm{O}, \delta \mathrm{D}$ and $d$ variations}

The surface values (top $1 \mathrm{~cm}$ ) of $\delta^{18} \mathrm{O}$ and $\delta \mathrm{D}$ are $\sim-32 \%$ and $\sim-257 \%$ o respectively (Fig. $6 a$ ). These values are in the range of expected modelled values for the altitude $2000 \mathrm{~m}$ a.s.l. (Jouzel and others, 1991; Dahe and others, 1994; Masson-Delmotte and others, 2008) and agree with the value for Allan Hills snow (-255\%) measured by Spaulding and others (2013) in 2009/10. The isotopic ratio profiles do not show a seasonal cycle (summer maxima) (Fig. 6a). Average values for $\delta \mathrm{D}$ are $\sim-270 \%$, with variations of $\pm 5 \%$, and average values of $\delta^{18} \mathrm{O}$ are $\sim-34 \%$, with variations of $\pm 2 \%$. The record shows significant depletion of heavy isotopes around $2.5 \mathrm{~m} \mathrm{(}-315 \%$ ofor $\delta \mathrm{D}$ (not shown), and $\sim-38.5 \%$ for $\delta^{18} \mathrm{O}$ (Fig. 6a)).

The deuterium excess $d\left(d=\delta \mathrm{D}-8 \times \delta^{18} \mathrm{O}\right.$ (Craig, 1961; Dansgaard, 1964)) is $\sim 0 \%$ on average, similar to measurements from the Dry Valleys (Masson-Delmotte and others, 2008), but shows large variations with depth (Fig. 6b). We can distinguish three clear peaks in $d$ : a negative peak of $\sim-6 \%$ o close to the surface, a positive peak of $\sim 11 \%$ around $50 \mathrm{~cm}$ depth, and another negative peak of $\sim-7 \%$ around $2.5 \mathrm{~m}$. The latter peak correlates with low values of $\delta \mathrm{D}$ and $\delta^{18} \mathrm{O}$, but the other two peaks are not reflected in $\delta \mathrm{D}$ and $\delta^{18} \mathrm{O}$. We also plotted $d_{\mathrm{L}}$ (Fig. 6b, blue line), which we define as the deuterium excess using the local meteoric waterline (Fig. 6c, solid line). The pattern of $d_{\mathrm{L}}$ is almost identical to $d$, but the excess is in the range 12$32 \%$ o ( 20\% higher than $d)$, without any negative values. For the following discussion, we will use $d$ to be consistent with existing literature. The values of $d$ (and $d_{\mathrm{L}}$ ) have a negative correlation with variations in snow density (or a positive correlation with porosity $(1-\rho / 917))$, with higher densities $(\rho)$ corresponding to lower $d$ values (Fig. 6b, inset, $d=49.1-0.084 \times \rho)$.

The relationship between $\delta^{18} \mathrm{O}$ and $\delta \mathrm{D}$ shows that most isotopic values are aligned along the local meteoric waterline (LMWL) with a slope of 8.6 (Fig. 6c, solid line). For reference, the slope of the Global MWL is 8, and the slope of the Antarctic Regional MWL is 7.75 (Masson-Delmotte and others, 2008).

\section{DISCUSSION}

\section{Physical properties: a result of post-depositional processes and high-impact deposition}

The snow profile close to the surface shows discrete layers (Fig. 2), which we interpret as representing either erosion events or periodically deposited snow, with no or very little deposition in between events, or a combination of both. The snow is likely to be deposited under extreme wind conditions and with high initial densities, and can therefore at times survive the strong erosion events in the area. It is, however, unclear how far the snow has been transported before final deposition. The SSA decreases exponentially with depth (Fig. 3a) and reflects the relative age of the snow (smaller SSA = older snow) better than density, which does not show a clear variation with depth. The density differences in the snow may be a result of (1) impact deposition at different wind speeds, with denser layers representing deposition events with higher winds, or (2) differences in post-depositional processes. Pfeffer and Mrugala (2002) showed that snow with a high initial density
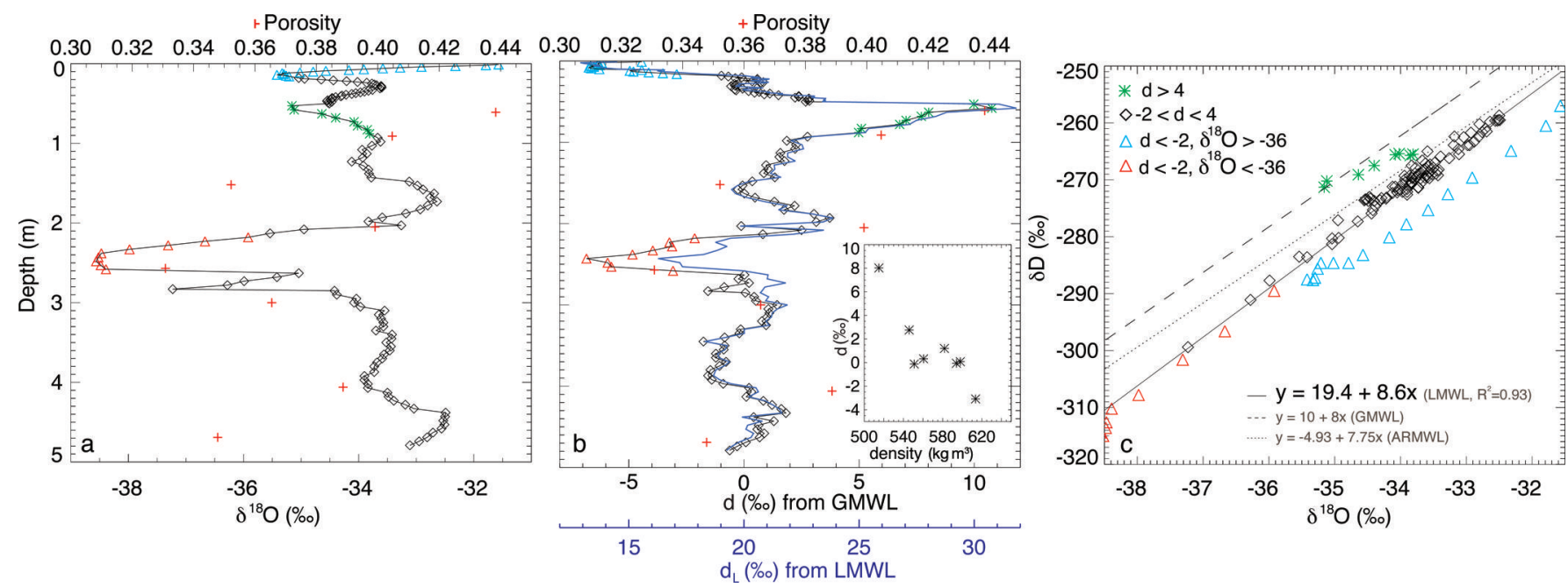

Fig. 6. Stable isotopes in the firn core. (a) $\delta^{18} \mathrm{O}$ isotopic ratio and porosity $(1-\rho / 917)$ with depth. (b) Deuterium excess $d$ and porosity with depth; blue line is deuterium excess $\left(d_{\mathrm{L}}\right)$ calculated using the local meteoric waterline; inset shows density vs deuterium excess $d$; red stars show porosity. (c) $\delta^{18} \mathrm{O}$ vs $\delta \mathrm{D}$; thick black line is the linear regression of our dataset (local meteoric waterline, $\mathrm{LMWL}$ ), dashed line is the global meteoric waterline $(\mathrm{GMWL})$ and dotted line is the Antarctic regional meteoric waterline (ARMWL) (after Masson-Delmotte and others, 2008). Diamonds are samples with $d$ between -2 and 4 , triangles are samples with $d<-2$ and crosses are samples with $d>4$. 
$\left(>400 \mathrm{~kg} \mathrm{~m}^{3}\right)$ does not allow for weak, low-density depthhoar layers, such as those expected under strong temperature gradients. Their findings are in agreement with ours and support the hypothesis that snow accumulation in the Allan Hills is a result of high-impact accumulation accompanied by strong winds with a high initial density.

The snow in the Allan Hills is to some degree similar to snow found in low-accumulation areas such as Taylor Dome (Steig and others, 2000; Neumann, 2003) or glazed sites in the megadunes (Albert and others, 2004; Courville and others, 2007), and referred to as 'extreme snow metamorphism'. Albert and others (2004) interpreted the thick coarsegrained layers, such as we found throughout the entire core, as periods of low accumulation, and they estimated the firn age in the top $1 \mathrm{~m}$ at their megadune site to be 40-140 years. Unlike the megadune measurements, our measurements show (1) no thin layers and (2) no faceted crystals. The lack of thin layers in our core implies long and sustained periods of low accumulation, in agreement with the low accumulation rate and persistent katabatic winds in the Allan Hills.

Even in cold conditions, vapour transport and metamorphism can create a high-permeability firn with large crystal sizes and large pore spaces (Fig. 3b), but not unusual densities (Albert, 2002). Sublimation and condensation within a snowpack are caused by water vapour diffusion and lead to changes in snow structure. Vapour diffusion is driven by microscopic pressure gradients resulting from (1) forced wind ventilation over rough surfaces or (2) temperature gradients, which can change direction daily or seasonally. Pinzer and Schneebeli (2009) showed that alternating temperature gradients do not necessarily produce faceted crystals, but result in rounded structures. They concluded that the 'metamorphic history is not uniquely reflected in snow morphology'. Brandt and Warren (1997) showed that inversions of daily temperature gradients in Antarctica (in their case at South Pole) exist, but that the variations are only significant in the top $20-30 \mathrm{~cm}$. They further showed that the difference in monthly average annual cycle is around $20 \mathrm{~K}$ at the surface and penetrates to a depth of $\sim 3.5 \mathrm{~m}$ (where the annual cycle is $7 \mathrm{~K}$ ), with October-February being warmer at the surface and MarchSeptember being colder at the surface. We think that such seasonal deep-penetrating alternating temperature-gradients together with the smaller daily gradients are generating pressure gradients that cause the observed snow structures. In addition, pressure gradients caused by forced ventilation over rough surfaces, caused by high winds, may increase vapour transport within the snowpack and therefore also contribute to snow metamorphism.

\section{Age estimates from ${ }^{210} \mathrm{~Pb}$ activity}

Except for the top $0.3 \mathrm{~m}$, we detected no ${ }^{210} \mathrm{~Pb}$ activity (Fig. 5), which implies either that (1) the snow below $0.3 \mathrm{~m}$ is older than 100 years or $(2)$ the ${ }^{210} \mathrm{~Pb}$ in this part of Antarctica is low. The latter explanation cannot account for the ${ }^{210} \mathrm{~Pb}$ in the top layer and is therefore unlikely. Suzuki and others (2004) discussed the implications of erosiondistribution processes of snow on the ice sheet and concluded that regions with katabatic winds, which include nearly all of East Antarctica, are likely to have irregular (but not zero) ${ }^{210} \mathrm{~Pb}$ profiles because of post-depositional migration of snow. The snow redistribution processes cannot however explain the complete lack of activity below $30 \mathrm{~cm}$.
Considering that we did not measure any ${ }^{210} \mathrm{~Pb}$ activity below $0.3 \mathrm{~m}$, we can assume that the snow below $0.3 \mathrm{~m}$ is older than 100 years. According to our calculations, based on those of Crozaz and others (1964), we estimate the accumulation rate to be $0.0075 \mathrm{~m} \mathrm{a}^{-1}$, and the bottom of the core to be $\sim 660$ years old. There is a possibility that we are overestimating the accumulation rate, perhaps because (1) the measured ${ }^{210} \mathrm{~Pb}$ activity in the surface layer reflects a smaller sublayer than the $30 \mathrm{~cm}$ that encompasses our top sample, or (2) we assume a constant accumulation rate. Varying accumulation rates, and especially lower accumulation rates during cold intervals, might also lead to an underestimation of the firn age. Furthermore, Figure 2 shows that discrete layers in the firn are likely due to wind erosion, which could also be a reason for the complete lack of ${ }^{210} \mathrm{~Pb}$ activity below $30 \mathrm{~cm}$.

\section{$\delta^{18} \mathrm{O}, \delta \mathrm{D}$ and $d$ variations: too small to be seasonal, too large to be climate events}

The stable isotope ratios in the near-surface samples are decoupled from the stratigraphic sequence (Fig. 2, discrete layers of physical properties (SSA, density) as opposed to the smooth isotopic profile), which indicates significant postdepositional fractionation. Isotope records at depth show little temporal variability, but with two major deviations at $\sim 0.5 \mathrm{~m}$ and $\sim 2.5 \mathrm{~m}$ (Fig. 6b), which could imply a climate signal. The periodic pattern near the surface is unlikely to be seasonal, because snow accumulation in this region is too low to preserve any seasonal temperature signals (an age estimate from ${ }^{210} \mathrm{~Pb}$ activity is an average of 20 years for the top $30 \mathrm{~cm}$ ). The inferred temperature variations from the larger isotopic variation at $\sim 2.5 \mathrm{~m}$ would be too small $\left(8^{\circ} \mathrm{C}\right.$ applying the Taylor Dome slope function; Steig and others, 1998), while seasonal variations in Antarctica are at least $20^{\circ} \mathrm{C}$ (Brandt and Warren, 1993; Courville and others, 2007).

To estimate the relative importance of temperature versus post-depositional modifications at the Allan Hills, we use published correlation slopes for temperature reconstructions from stable water isotopes (Steig and others, 1998). Applied to the the negative peak at $\sim 2.5 \mathrm{~m}$, we obtain a temperature decrease and a subsequent increase of $\sim 8^{\circ} \mathrm{C}$ or more. This approximation is clearly larger than any feasible centennial temperature variability in the past millennium. For comparison, the West Antarctic ice sheet (WAIS) is estimated to have been $0.5-0.28^{\circ} \mathrm{C}$ colder during the LIA than the last 100 year average (Orsi and others, 2012), while the Ross Sea region cooled by about $2{ }^{\circ} \mathrm{C}$ during the LIA (Bertler and others, 2011). We can therefore rule out the idea that the isotopic changes in our core uniquely reflect site temperature at the time of precipitation. Considering the evidence for highly metamorphosed snow (e.g. high-density with large pore spaces and ice structures, stable structures thoughout the core, and a continuous decrease in SSA with depth), we interpret the strong isotopic signal at $2.5 \mathrm{~m}$ to be caused by post-depositional processes, in particular forced ventilation over rough surfaces and alternating temperaturegradients that cause the microscopic pressure gradients necessary for snow metamorphism. Furthermore, we think that air exchange between the atmosphere and the snowpack is necessary to explain the strong depletion of stable isotopes at this depth. These processes are enhanced by strong wind erosion that keeps the snow exposed to nearsurface processes for an extended time. This is important because reduced accumulation during glacial time periods 
leads to extremely long bubble close-off times (for Vostok ice core, the age of the firn at bubble close-off is 6000 years; Barnola and others, 1991), exposing the snow and firn crystals for long periods to high surface winds and temperature gradients and thus to changes in humidity and temperature. To a lesser degree, the isotopic signal can also be affected by depositional processes (wind scour and surface microtopography; Vimeux and others, 2001).

Negative deuterium-excess $d$ values have previously been associated with isotope-enriched air masses that are precipitated at extremely low temperatures (Kavanaugh and Cuffey, 2003), with wind ablation effects which reduce accumulation and therefore 'increase the residence time of snow crystals in the surface zone characterised by strong temperature gradients' (Masson-Delmotte and others, 2008), and with long and continuous post-depositional evaporation/sublimation processes, lower temperatures and reduced relative humidity (Bertler and others, 2011), perhaps sourced from a larger, more active Ross Sea polynya due to stronger katabatic winds. The continuous recrystallization and large mass turnover as observed by Pinzer and others (2012) and modelled by Steen-Larsen and others (2014) lead to a rapid imprint of changes in near-surface water vapour isotopic composition into surface snow (Steen-Larsen and others, 2014). We conclude that the negative $d$ values at the Allan Hills could be caused by (1) post-depositional effects due to forced ventilation and strong temperature gradients in the snowpack, and (2) incursions of local marine air masses that originate from the Ross Sea polynya.

In Figure 6c, we show the slope relationship between $\delta D$ and $\delta^{18} \mathrm{O}$ and define four separate data clusters in comparison to the LMWL (slope 8.6), global meteoric waterline (GMWL, slope 8.0) and the best-fit line for a large Antarctic dataset (slope 7.75) (Masson-Delmotte and others, 2008), which we define here as the Antarctic regional meteoric waterline (ARMWL). Two groups $\mathrm{A}(-2<d<4 \%$, most of the core, black diamonds) and B $(d<-2 \%$ and depleted $\delta^{18} \mathrm{O}$, red triangles) fall onto the LMWL. Group B represents samples from the $2.5 \mathrm{~m}$ deep isotope peak ( 260440 years), indicating that the low isotope values might indeed reflect lower local temperatures during precipitation. In contrast, group $\mathrm{C}$ samples with low $d(d<-2 \%$ o) and high $\delta^{18} \mathrm{O}\left(\delta^{18} \mathrm{O}>-36 \%\right.$, Fig. 6c, blue triangles), located in the top $0.2 \mathrm{~m}(\sim 0-30$ years), are depleted in $\delta \mathrm{D}$, and are aligned along a line with a slope parallel to but below LMWL $\delta D$. This finding indicates that these samples originate from an air mass characterized by higher humidity during relatively high temperatures than do the remaining core and are likely to represent recent snow precipitation, while the remaining core (even the samples along the $\mathrm{LMWL}$ ) is older with stronger post-depositional modifications. Group D consists of samples with higher than average deuterium excess $(d>4 \%$, green asterisks), located around $0.5 \mathrm{~m}$ ( 70-130 years), which are aligned along a lower slope, indicative of more arid conditions and stronger postdepositional modification.

The isotopic enrichment that follows the removal of water vapour from firn into the atmosphere is more common and can lead to a decrease in snow density (Satake and Kawada, 1997; Neumann, 2003). A net transport of water vapour into the snow is necessary to produce the strong depletion of heavy isotopes and snow densification such as we observe around $2.5 \mathrm{~m}$ in the Allan Hills core. This net transport is only possible if the firn stays colder than the air for prolonged periods. Cooling of snow and net heat loss to the atmosphere can be achieved in regions of strong winds either by advection of sensible heat through ventilation of cold air or latent cooling through sublimation. While possible for areas with strong winds, the depletion of isotopes is not widely spread in nature (Neumann, 2003). The ventilation-driven post-depositional modifications are likely to increase during glacial periods as a result of increased wind speed and increased surface roughness. Another process that could lead to the observed isotopic depletion and reduced deuterium excess at $2.5 \mathrm{~m}$ could be a temporary change in the moisture source, with most of the moisture coming from the polar plateau with lower isotopic values. A change in the moisture source could also be caused by a sudden shift in atmospheric moisture transport to Antarctica (Kavanaugh and Cuffey, 2003; MassonDelmotte and others, 2010; Scarchilli and others, 2010), shifting the moisture source to higher latitudes enabled by increased westerlies.

We observe a statistically significant negative correlation between $d$ and density (Fig. 6b, inset) below $60 \mathrm{~cm}$, while there is no correlation between density and $\delta \mathrm{D}$ or $\delta^{18} \mathrm{O}$. This finding may be explained by a net deposition of water vapour in the snow from the atmosphere, and by recrystallization of the snowpack accompanied by kinetic fractionation (Steen-Larsen and others, 2014). Mass gain has previously been observed in experiments for layers where depletion of heavy isotopes occurred (Sommerfeld and others, 1991). We see no correlation between the heavy isotope concentration and density, but only between $d$ and density. Our observed correlation could be coincidental and more data are needed to investigate this relationship.

\section{Synthesis}

The Allan Hills region is characterized by high katabatic wind speeds and very low or negative average accumulation. A few locations are accumulation areas because of their topographical setting. The low ice-field velocities mean that these topographic depressions exist for many hundreds of years.

Micro-CT measurements of near-surface samples show high density and high SSA. This is typical for snow that has been transported by wind. However, such high initial densities $\left(>500 \mathrm{~kg} \mathrm{~m}^{-2}\right.$ ) are rare, even in regions with high winds. The most likely explanation for the high density at the surface or for snow without significant overburden pressure is high-impact accumulation caused by wind. We think that accumulation only survives erosion in this region if snow is deposited at high wind speed and, consequently, with an initial density close to the random close-packing limit, and thus more resistant to erosion. The initial high density caused by wind deposition results in a viscosity that is so high that, at the prevailing low temperatures, the temperature-dependent snow creep is minimized and compaction is slow.

In addition, we argue that post-depositional water vapour movement in the firn, and water vapour exchange between the firn and the atmosphere arises from secondary processes that lead to the observed high densities, without the need for overburden pressure and compaction. Water vapour movement is caused by microscopic pressure gradients that are induced either by (1) forced ventilation through wind or (2) macroscopic temperature gradients. We hypothesize that highly metamorphosed snow and conservation of density is 
a combined effect of a high-density deposition at very high wind speed, a topographically unique location, alternating temperature gradient metamorphism and wind-induced moisture transport over centuries.

Water vapour movement between the firn and the atmosphere also modifies isotopic ratios, especially in windy, low-accumulation areas where (1) snow is exposed to near-surface ventilation and potential vapour deposition from the air for longer periods of time (air can change isotopic composition depending on air mass trajectories), and (2) snow is exposed to near-surface alternating temperature gradients that accelerate water vapour movement for a long time. Depending on the temperature differences between the air and the firn, air humidity and the fraction of water vapour lost to the atmosphere, forced ventilation through wind can either lead to enrichment or depletion of $\delta \mathrm{D}$ and $\delta^{18} \mathrm{O}$, and to changes in $d$ through kinetic fractionation. On the basis of the differences between the near-surface stratigraphy and the stable isotope signal, with stratigraphy showing discrete layers while the isotopic composition shows a smooth profile, we argue that the isotopic composition in the entire core is postdepositionally modified. The observed peaks in $\delta \mathrm{D}$ and $\delta^{18} \mathrm{O}$, and in $d$ could be caused by enhanced postdepositional processes through (1) stronger winds, (2) lower accumulation rates causing longer exposures at the surface or (3) stronger temperature gradients between the firn and the overlying atmosphere due to changes in the inversion layer, and (4) relative humidity at the source region. Such conditions can be caused by a colder climate interval. Other reasons for large changes in isotopic composition could be sudden shifts in atmospheric moisture transport paths (Masson-Delmotte and others, 2010), changes in moisture sources or rapid imprints of changes in the near-surface atmosphere isotopic composition into surface snow (SteenLarsen and others, 2014), a seasonal change in snow precipitation, and continuous recrystallization (Pinzer and others, 2012; Steen-Larsen and others, 2014).

Our results support the hypothesis that the unique snow structure and the stable isotope composition in the Allan Hills snow is caused by (1) microscopic pressure gradients in the firn that result from either forced ventilation over rough surfaces in the presence of wind or the alternating seasonal temperature-gradients that this snow has been exposed to, because of low accumulation rates that cause the snow to stay near the surface for a long time, (2) highimpact wind-driven snow deposition, which results in a high initial density, and (3) increased vapour transport due to forced wind ventilation and air exchange between the atmosphere and the snowpack, which is active during the long residence time of snow near the surface. Furthermore, based on the lack of ${ }^{210} \mathrm{~Pb}$ activity below $30 \mathrm{~cm}$, we hypothesize that the measured firn core is up to 660 years old and maybe older, and is a possible analogue for cold and windy glacial conditions, and with accumulation lower than occurs today. More data are needed to fully test our hypothesis.

Post-depositional processes make this dataset, and snow/ firn from low-accumulation areas in general, challenging for use as a temperature proxy for palaeoclimate research. Even for samples that might not be affected by post-depositional processes, the potential old age and the long residence time of the firn near the surface have probably enhanced diffusion and acted to homogenize the isotope composition and lose any seasonal, annual or even decadal signals. Still, we can clearly see at least two possible climate signals in our $5 \mathrm{~m}$ core $(0.5 \mathrm{~m}$ and $2.5 \mathrm{~m})$, and we therefore conclude that even sites with very low accumulation might preserve climate signals, though their interpretation remains challenging. To take full advantage of the exceptional data from deep, polar ice cores, it is critical to improve our understanding of post-depositional processes as well as long-term isotope diffusion.

\section{SUMMARY}

Extreme snow metamorphism results in major structural changes and can be accompanied by significant postdepositional changes in stable isotope concentrations. Such highly metamorphosed snow has been little studied to date, but is relevant for interpretation of ice-core records in the context of past climatic changes. We analysed a $5 \mathrm{~m}$ firn core in the Allan Hills to improve our understanding of snow metamorphism and isotopic composition in low-accumulation regions. We determined the physical properties using computer tomography, and measured the stable water isotope ratios $\delta \mathrm{D}$ and $\delta^{18} \mathrm{O}$ and ${ }^{210} \mathrm{~Pb}$ activity.

We found highly metamorphosed snow with high densities and little layering accompanied by rounded and stable ice structures prevalent throughout the core. The snow has gone through multiple complete recrystallization cycles. We interpret the discrete layering near the surface to be erosion events. Stable water isotopes show no seasonal signature and the isotopic evolution at the surface does not follow the discrete layers in the stratigraphic sequence and must therefore have been formed by post-depositional processes that are affected by local climate. $\delta \mathrm{D}$ and $\delta^{18} \mathrm{O}$ at $\sim 2.5 \mathrm{~m}$ indicate at least one climate event in the past that differs from current conditions. The deuterium excess $d$ at $\sim 0.5 \mathrm{~m}$ indicates an additional climate event.

Possible post-depositional processes that change the firn structure as well as stable isotope ratios are sublimation, condensation and water vapour diffusion within the firn, as well as water vapour exchange between the firn and the atmosphere. These processes are caused by vapour-pressure gradients in the snowpack or forced ventilation in the presence of wind (Neumann and Waddington, 2004; Sokratov and Golubev, 2009) or macroscopic temperature gradients. Both of these processes are present in the dry region of the Allan Hills, where high winds are common, and where accumulation is so low that snow is exposed to near-surface processes for long periods. Furthermore, wind-driven ablation (scouring) and redeposition could also affect isotopic ratios to some extent, by relocation of original snowfall.

${ }^{210} \mathrm{~Pb}$ activity, because of the constant flux and short halflife, can be used to determine the age of the firn. There was no ${ }^{210} \mathrm{~Pb}$ activity below $30 \mathrm{~cm}$, which implies that most of the core is more than 100 years old. The observed discrete layers in the near-surface potentially explain the total lack of ${ }^{210} \mathrm{~Pb}$ activity below $30 \mathrm{~cm}$. Age estimates based on ${ }^{210} \mathrm{~Pb}$ activity in the surface layer indicate that the bottom of the core is at least $\sim 660$ years old (AD 1350).

We discussed the possible effects of low accumulation and increased wind speeds, such as are typical for cold climate intervals, on firn microstructure and stable water isotope signature. We postulate that such structure is caused by the combination of snow deposition at high wind speed and decades of temperature-gradient driven metamorphic 
growth in the near surface (due to prolonged exposure to seasonal temperature cycling and forced ventilation) and is likely to be accompanied by altered isotopic concentrations, making it highly relevant for palaeoclimate reconstruction (Courville and others, 2007; Severinghaus and others, 2010). Our findings support the hypothesis that the measured firn core in the Allan Hills is old for near-surface snow and might be a valid analogue for cold and windy glacial conditions with accumulation lower than that observed today.

Therefore, we suggest that future research targets cores from near-zero accumulation areas to better understand the range of isotopic changes during ice ages, when accumulation was lower than it is today. In particular, there is need for higher vertical-resolution firn cores over a larger horizontal area, high-frequency radar and a better understanding of the ice flow in the accumulation areas of the Allan Hills and other low-accumulation areas. Understanding the processes that alter stable isotopes and firn microstructure will improve past temperature/accumulation estimates from ice-core records and help us to better understand past climate variations.

\section{ACKNOWLEDGEMENTS}

The fieldwork was supported by US National Science Foundation grant ANT-07-39779 to the University of Washington (principal investigator Stephen Warren). Melanie Fitzpatrick organized the logistics, and both she and Regina Carns participated in the fieldwork and discussions about the measurements. Logistical support by the US Antarctic Program was excellent. We thank Matthias Jaggi for help in the cold laboratory, Huw Horgan for numerous discussions, and two reviewers whose comments greatly improved the manuscript. Ruzica Dadic was supported by a postdoctoral fellowship from the Swiss National Science Foundation (Project 124273) and by the Marsden Fund of the Royal Society of New Zealand (VUW1314). Isotope measurements were supported through GNS Science funded from the New Zealand Ministry for Business, Innovation and Employment (grant 540GCT32).

\section{REFERENCES}

Albert MR (2002) Effects of snow and firn ventilation on sublimation rates. Ann. Glaciol., 35, 52-56 (doi: 10.3189/ 172756402781817194)

Albert MR, Shuman CA, Courville ZR, Bauer R, Fahnestock MA and Scambos TA (2004) Extreme firn metamorphism: impact of decades of vapor transport on near-surface firn at a lowaccumulation glazed site on the East Antarctic plateau. Ann. Glaciol., 39, 73-78 (doi: 10.3189/172756404781814041)

Barnola JM, Pimienta P, Raynaud D and Korotkevich S (1991) $\mathrm{CO}_{2}{ }^{-}$ climate relationship as deduced from the Vostok ice core: a reexamination based on new measurements and on a re-evaluation of the air dating. Tellus B, 43(2), 83-90

Bertler NAN, Mayewski PA and Carter L (2011) Cold conditions in Antarctica during the Little Ice Age - implications for abrupt climate change mechanisms. Earth Planet. Sci. Lett., 308(1-2), 41-5 (doi: 10.1016/j.epsl.2011.05.021)

Bindschadler R and 8 others (2008) The LANDSAT mosaic image of Antarctica. Remote Sens. Environ., 112(12), 4214-4226 (doi: 10.1016/j.rse.2008.07.006)

Bintanja R (1999). On the glaciological, meteorological, and climatological significance of Antarctic blue ice areas. Rev. Geophys., 37(3), 337-359 (doi: 10.1029/1999RG900007)
Bintanja R and Reijmer CH (2001) Meteorological conditions over Antarctic blue ice areas and their influence on the local surface mass balance. J. Glaciol., 47(156), 37-50 (doi: 10.3189/ 172756501781832557)

Bintanja R and Van den Broeke MR (1995) The surface energy balance of Antarctic snow and blue ice. J. Appl. Meteorolol,, 34, 902-926 (doi: 10.1175/1520-0450(1995)034<0902:TSE$\mathrm{BOA}>2.0 . \mathrm{CO} ; 2)$

Brandt RE and Warren SG (1993) Solar heating rates and temperature profiles in Antarctic snow and ice. J. Glaciol., 39, 99-110

Brandt RE and Warren SG (1997) Temperature measurements and heat transfer in near-surface snow at the South Pole. J. Claciol., 43(144)

Cappa CD, Hendricks MB, DePaolo DJ and Cohe RC (2003) Isotopic fractionation of water during evaporation. J. Geophys. Res., 108, D164525 (doi: 10.1029/2003JD003597)

Cassidy WA, Harvey RP, Schutt J, Delisle G and Yanai K (1992) The meteorite collection sites of Antarctica. Meteoritics, 27, 490-525

Colbeck SC (1989) Air movement in snow due to windpumping. J. Glaciol., 35(120), 209-213

Courville ZR, Albert MR, Fahnestock MA, Cathles IV LM and Shuman CA (2007) Impacts of an accumulation hiatus on the physical properties of firn at a low-accumulation polar site. J. Geophys. Res., 112, F02030 (doi: 10.1029/2005JF000429)

Craig H (1961) Isotopic variations in meteoric waters. Science, 113, $1702-1703$

Crozaz G, Picciotto E and De Bruick W (1964) Antarctic snow chronology with $\mathrm{Pb}^{210}$. J. Geophys. Res., 69(12), 2596-2604

Cuffey KM and Steig EJ (1998) Isotopic diffusion in polar firn: implications for interpretation of seasonal climate parameters in ice-core records, with emphasis on central Greenland. J. Glaciol., 44(147), 273-284

Cuffey KM, Clow GD, Alley RB, Stuiver M, Waddington ED and Saltus RW (1995) Large Arctic temperature change at the Wisconsin-Holocene glacial transition. Science, 270(5235), 455-458 (doi: 10.1126/science.270.5235.455)

Cunningham J and Waddington ED (1993) Air flow and dry deposition of non-sea salt sulfate in polar firn: paleoclimatic implications. Atmos. Environ., 27A(17-18), 2943-2956 (doi: 10.1016/0960-1686(93)90327-U)

Dadic R, Mullen PC, Schneebeli M, Brandt RE and Warren SG (2013) Effects of bubbles, cracks, and volcanic tephra on the spectral albedo of bare ice near the Transantarctic Mountains: implications for sea-glaciers on Snowball Earth. J. Geophys. Res., 118, 1658-1676 (doi: 10.1002/jgrf.20098)

Dahe Q, Petit JR, Jouzel J and Stievenard M (1994) Distribution of stable isotopes in surface snow along the route of the 1990 international Trans-Antarctica expedition. J. Glaciol., 40(134), 107-118

Dansgaard W (1964) Stable isotopes in precipitation. Tellus, 16(4), 436-468

Delmotte M, Masson V and Jouzel J (2000) A seasonal deuterium excess signal at Law Dome, coastal Antarctica: a Southern Ocean signature. J. Geophys. Res., 105(D6), 7187-7197 (doi: 10.1029/1999JD901085)

Ekaykin AA, Lipenkov VY, Barkov NI, Petit JR and MassonDelmotte V (2002) Spatial and temporal variability in isotope composition of recent snow in the vicinity of Vostok station, Antarctica: implications for ice-core record interpretation Ann. Glaciol., 16 181-186 (doi: 10.3189/172756402781816726)

Ekaykin AA, Hondoh T, Lipenkov VY and Mayamoto A (2009) Postdepositional changes in snow isotope content: preliminary results of laboratory experiments. Climate Past Discuss., 5, 2239-2267 (doi: 10.5194/cpd-5-2239-2009)

EPICA Community Members (2004) Eight glacial cycles from an Antarctic ice core. Nature, 429(6992), 623-628 (doi: 10.1038/ nature02599)

Epstein S, Sharp RP and Gow AJ (1965) 6-year record of oxygen and hydrogen isotope variations in South Pole firn. J. Geophys. Res., 70(8), 1809-1814 (doi: 10.1029/JZ070i008p01809) 
Friedman I, Benson CS and Gleason J (1991) Isotopic changes during snow metamorphism. In Taylor HP, O'Neill JR and Kaplan IR eds Stable isotope geochemistry: a tribute to Samuel Epstein. (Special Publication 3) Geochemical Society, San Antonio, TX, 211-221

Gäggeler HW, Von Gunten HR, Oeschger $\mathrm{H}$ and Schotterer $\mathrm{U}$ (1983) ${ }^{210} \mathrm{~Pb}$-dating of cold alpine firn/ice cores from Colle Gnifetti, Switzerland. J. Glaciol., 29(101), 165-177

Harvey RP and 6 others (1998) Meteoritic event recorded in Antarctic ice. Geology, 26, 607-610

Heggli M, Frei E and Schneebeli M (2009) Snow replica method for three-dimensional X-ray microtomographic imaging. J. Glaciol., 55(192), 631-639 (doi: 10.3189/002214309789470932)

Hildebrand T and Rüegsegger P (1997) A new method for the model-independent assessment of thickness in three-dimensional images. J. Microsc., 185(1), 67-75 (doi: 10.1046/j.13652818.1997.1340694.x)

Johnsen J, Clausen HB, Cuffey KM, Hoffmann G, Schwander J and Creyts TT (2000) Diffusion of stable isotopes in polar firn: the isotope effect firn diffusion. In Hondoh T ed. Physics of ice core records. Hokkaido University Press, Sapporo, 121-140

Jouzel J, Koster RD, Suozzo RJ, Russel GL, White JCW and Broecker WS (1991) Simulations of the HDO and $\mathrm{H}_{2}{ }^{18} \mathrm{O}$ atmospheric cycles using the NASA Giss General Circulation model sensitivity experiments for present-day conditions. J. Geophys. Res. Atmos., 96(D4), 7495-7507 (doi: 10.1029/90JD02663)

Jouzel J and 12 others (1997) Validity of the temperature reconstruction from water isotopes in ice cores. J. Geophys. Res. Oceans, 102(C12), 26 471-26 487 (doi: 10.1029/97JC01283)

Jouzel J and 31 others (2007a) Orbital and millennial Antarctic climate variability over the past 800,000 years. Science, 317(5839), 793-796 (doi: 10.1126/science.1141038)

Jouzel J and 8 others (2007b) The GRIP deuterium-excess record. Quat. Sci. Rev., 26, 1-17 (doi:10.1016/j.quascirev.2006.07.015)

Kavanaugh JL and Cuffey KM (2003) Space and time variation of $\delta^{18} \mathrm{O}$ and $\delta \mathrm{D}$ in Antarctic precipitation revisited. Global Biogeochem. Cycles, 17(1) (doi: 10.1029/2002GB001910)

Langway CC Jr (1967) Stratigraphic analysis of a deep ice core from Greenland. CCREL Res. Rep. 77

Lorius C and Merlivat L (1977) Distribution of mean surface stable isotope value in East Antarctica: observed changes with depth in the coastal area. IAHS Publ. 118, 127-137

Luz B, Barkan E, Yam R and Shemesh A (2009) Fractionation of oxygen and hydrogen isotopes in evaporating water. Geochim. Cosmochim. Acta, 73, 6697-6703 (doi: 10.1016/j.gca.2009. 08.008)

McConnell JR, Bales RC, Stewart RW, Thompson AM, Albert MR and Ramos $R$ (1998) Physically based modeling of atmosphereto-firn transfer of $\mathrm{H}_{2} \mathrm{O}_{2}$ at South Pole. J. Geophys. Res., 103(D9), 10561-10570

Masson-Delmotte $V$ and 25 others (2006) Past and future polar amplification of climate change: climate model intercomparisons and ice-core constraints. Climate Dyn., 27(4), 513-529 (doi: 10.1007/s00382-005-0081-9)

Masson-Delmotte $\mathrm{V}$ and 40 others (2008) A review of Antarctic surface snow isotopic composition: observations, atmospheric circulation, and isotopic modeling. J. Climate, 21(13), 3359-3387 (doi: 10.1175/2007JCLI2139.1)

Masson-Delmotte $V$ and 22 others (2010) Abrupt change of Antarctic moisture origin at the end of Termination II. Proc. Natl Acad. Sci. USA, 107(27), 12 091-12 094 (doi: 10.1073/pnas.0914536107)

Merlivat L (1978) Molecular diffusivities of $\mathrm{H}_{2} \mathrm{O}^{16} \mathrm{O}, \mathrm{HD}^{16} \mathrm{O}$, and $\mathrm{H}_{2} \mathrm{O}^{18} \mathrm{O}$ in gases. J.Chem. Phys., 69(6), 2864-2871

Merlivat L and Jouzel J (1979) Global climatic interpretation of the deuterium-oxygen 18 relationship for precipitation. J. Geophys. Res., 84(NC8), 5029-5033 (doi: 10.1029/JC084iC08p05029)

Morse DL and 7 others (1999) Accumulation rate measurements at Taylor Dome, East Antarctica: techniques and strategies for mass balance measurements in polar environments. Geogr. Ann. A, 81(4), 683-694
Moser H and Stichler W (1974) Deuterium and oxygen-18 contents as an index of the properties of snow covers. IAHS Publ. 114 (Symposium at Grindelwald 1974 - Snow Mechanics), 122-135

Neumann TA (2003) Effects of firn ventilation on geochemistry of polar snow. (PhD thesis, University of Washington)

Neumann TA and Waddington ED (2004) Effects of firn ventilation on isotopic exchange. J. Glaciol., 50(169), 183-194 (doi: 10.3189/172756504781830150)

Orsi AJ, Cornuelle BD and Severinghaus JP (2012) Little Ice Age cold interval in West Antarctica: evidence from borehole temperature at the West Antarctic Ice Sheet (WAIS) Divide. Geophys. Res. Lett., 39, L09710 (doi: 10.1029/2012GL051260)

Parrenin F and 9 others (2013) Synchronous change of atmospheric $\mathrm{CO}_{2}$ and Antarctic temperature during the last deglacial warming. Science, 339(6123), 1060-1063 (doi: 10.1126/ science.1226368)

Pfeffer WT and Mrugala R (2002) Temperature gradient and initial snow density as controlling factors in the formation and structure of hard depth hoar. J. Glaciol., 48(163), 485-494 (doi: 10.3189/172756502781831098)

Pinzer B and Schneebeli M (2009) Snow metamorphism under alternating temperature gradients: morphology and recrystallization on surface snow. Geophys. Res. Lett., 36, L23503 (doi: 10.1029/2009GL039618)

Pinzer B, Schneebeli M and Kaempfer TU (2012) Vapor flux and recrystallization during dry snow metamorphism under a steady temperature gradient as observed by time-lapse microtopography. Cryosphere, 6, 1141-1155 (doi: 10.5194/tc-6-1141-2012)

Sanak J and Lambert G (1977) Lead 210 of climatic changes at South Pole. Geophys. Res. Lett., 4(9), 367-359

Satake H and Kawada H (1997) The quantitative evaluation of sublimation and the estimation of original hydrogen and oxygen isotope ratios of a firn core at East Queen Maud Land Antarctica. Bull. Glacier Res., 15, 93-97

Scarchilli C, Frezzotti M and Ruti PM (2010) Snow precipitation at four ice core sites in East Antarctica: provenance, seasonality and blocking factors. Climate Dyn., 37(9), 2107-2125

Schneebeli M and Sokratov SA (2004) Tomography of temperature gradient metamorphism in snow and changes in heat conductivity. Hydrol. Process., 18, 3655-3665 (doi: 10.1002/hyp.5800)

Severinghaus JP and 12 others (2010) Deep air convection in the firn at a zero-accumulation site, central Antarctica. Earth Planet. Sci. Lett., 293, 359-367 (doi:10.1016/j.epsl.2010.03.003)

Sokratov SA and Golubev VN (2009) Snow isotopic content change by sublimation. J. Glaciol., 55(193), 823-828 (doi: 10.3189/ 002214309790152456)

Sommerfeld RA, Friedman I and Nilles M (1987) The fractionation of natural isotopes during temperature gradient metamosphism. In Jones HG and Orville-Thomas WJ eds Seasonal snow covers: physics, chemistry, hydrology. (NATO ASI Series 211) Springer, Dordrecht, 95-105

Sommerfeld RA, Judy C and Friedman I (1991) Isotopic change during the formation of depth hoar in experimental snowpacks. In Taylor HP, O'Neill JR and Kaplan IR eds Stable isotope geochemistry: a tribute to Samuel Epstein. (Special Publication 3) Geochemical Society, San Antonio, TX, 205-209

Spaulding NE and 7 others (2012) Ice motion and mass balance at the Allan Hills blue ice area, Antarctica, with implications for paleoclimate reconstructions. J. Glaciol., 58(208), 399-406 (doi: 10.3189/2012JoG11J176)

Spaulding NE and 9 others (2013) Climate archives from 90 to $250 \mathrm{ka}$ in horizontal and vertical ice cores from the Allan Hills Blue Ice Area, Antarctica. Quat. Res., 80, 562-574 (doi: 10.1016/j.yqres.2013.07.004)

Steen-Larsen HC and 18 others (2014) What controls the isotopic composition of Greenland surface snow? Climate Past, 10(1), 377-392

Steig EJ and 8 others (1998) Synchronous climate changes in Antarctica and the North Atlantic. Science, 282(5386), 92-95 (doi: 10.1126/science.282.5386.92) 
Steig EJ and 7 others (2000) Wisconsinan and Holocene climate history from an ice core at Taylor Dome, western Ross Embayment, Antarctica. Geogr. Ann. A, 82A(2-3), 213-235 (doi: 10.1111/j.0435-3676.2000.00122.x)

Stichler WU and 6 others (2001) Influence of sublimation on stable isotope records recovered from high-altitude glaciers in the tropical Andes. J. Geophys. Res. Atmos., 106(D19), 22 613-22 620 (doi: 10.1029/2001JD900179)

Suzuki T, Kamiyama K, Furukawa T and Fujii Y (2004) Lead-210 profile in firn layer over Antarctic ice sheet and its relation to the snow accumulation environment. Tellus, 56B, 85-92 (doi: 10.1111/j.1600-0889.2004.00089.x)

Town MS, Warren SG, Walden VP and Waddington ED (2008) Effect of atmospheric water vapor on modification of stable isotopes in near-surface snow on ice sheets. J. Geophys. Res., 113, D24303 ( doi:10.1029/2008JD009852)
Vimeux F and 7 others (2001) Holocene hydrological cycle changes in the Southern Hemisphere documented in East Antarctic deuterium excess records. Climate Dyn., 17(7), 503-513 (doi: 10.1007/PL00007928)

Waddington ED, Cunningham J and Harder SL (1996) The effects of snow ventilation on chemical concentrations. In Wolff $E$ and Bales RC eds Chemical exchange between the atmosphere and polar snow. Springer Verlag, Berlin and Heidelberg, 403-451 Waddington ED, Steig EJ and Neumann TA (2002) Using characteristic times to assess whether stable isotopes in polar snow can be reversibly deposited. Ann. Glaciol., 35, 118-124 (doi: 10.3189/172756402781817004)

Whillans IM and Cassidy WA (1983) Catch a falling star: meteorites and old ice. Science, 222, 55-57

Whillans IM and Grootes PM (1985) Isotopic diffusion in cold snow and firn. J. Geophys. Res., 90(D2), 3910-3918

MS received 11 February 2015 and accepted in revised form 25 September 2015 